\title{
Autumn diet of the edible dormouse in Galicia, northwest Spain
}

\author{
Antonio GIGIREY and José M. REY
}

\begin{abstract}
Gigirey A. and Rey J. M. 1998. Autumn diet of the edible dormouse in Galicia, northwest Spain. Acta Theriologica 43: 325-328.

The autumn diet of the edible dormouse Glis glis Linnaeus, 1776 in northwest Spain was investigated on the basis of analysis of the stomach contents of 32 individuals captured in September and October of 1985 and 1986. Remains of Quercus robur acorns and Corylus avellana hazelnuts accounted for $86.5 \%$ of the total dry weight of the 32 samples, while blackberry remains accounted for $10.2 \%$. Remains of vegetative plant structures (leaves, etc) accounted for only $3.3 \%$ of total dry weight. Insect remains were frequently present, but in very small amounts (about $0.01 \%$ of total dry weight). Dormouse hairs and ectoparasites were also frequently present, presumably as a result of accidental ingestion during grooming.
\end{abstract}

Departamento de Biología Animal, Facultad de Biología, Universidad de Santiago de Compostela, Campus Sur s/n, 15706 Santiago de Compostela, España, e-mail: batonho@usc.es, bavert1@usc.es

Key words: Glis glis, diet, Spain

\section{Introduction}

The edible dormouse (Glis glis Linnaeus, 1776) occurs in oak and beech woodlands in the northern part of the Iberian Peninsula. Previous studies have shown this species to be basically herbivorous (Kahmann 1965, Holišova 1968, Castroviejo et al. 1974, Morris and Hoodless 1992, Castién 1994, Rodolfi 1994); in typical habitats, feeding upon insects and small vertebrates occurs only occasionally (Vietinghoff-Riesch 1960, Kahmann 1965, Storch 1978, Robel and Leitenbacher 1993). Carnivory appears to play a more important role in some atypical habitats (Franco 1990).

In the work reported here we investigated the composition of the autumn diet of edible dormice in the westernmost part of their range, in a habitat that can be considered optimal.

\section{Material and methods}

The study was carried out in the Montes do Invernadeiro Nature Reserve in northwest Spain. This area (altitude 1000-1300 m a.s.l.) is largely occupied by montane deciduous woodland with strong Atlantic influence (Castroviejo 1977). The dominant tree species is Quercus robur, other common species being Acer pseudoplatanus, Corylus avellana, Fraxinus excelsior, Betula celtiberica, and Sorbus aucuparia. The understorey is dominated by Ilex aquifolium and Rubus sp. 
The diet of the edible dormouse was investigated on the basis of analysis of the stomach contents of 32 individuals captured in September and October of 1985 and 1986 by snap traps baited with apple. After capture, the stomach and a part of the small intestine were dissected out and preserved in $5 \%$ formalin until examination. Gastrointestinal contents were processed by the method of Korschgen (1971); after removing from the formalin they were dried in a oven at $60-80{ }^{\circ} \mathrm{C}$, weighed on a balance with precision of $\pm 0.001 \mathrm{~g}$, and examined under a stereomicroscope at a magnification of $10-50 \times$. Food items were identified with the aid of a reference collection of material collected over the study period at the study site. Hairs were identified with the aid of Teerink (1991).

\section{Results}

The majority of the 32 animals captured were subadults, so that comparisons of diet among age-groups were not possible. Seventeen individuals were male and 14 female; sex could not be determined in 1 individual.

The results revealed a basically herbivorous diet (Table 1). The most frequent remains were of Quercus robur acorns and Corylus avellana hazelnuts (as we had reported previously; see Gigirey et al. 1996). Blackberry seeds were also frequent, with up to 166 seeds in one individual's stomach. Leaf and stem remains were present in small amounts. Birch seeds appear to be an occasional food item.

Animal remains - in all cases of insects and/or arachnids - were frequently present (18 of the 32 stomachs), but in very small amounts. Twelve of the 18 stomachs contained remains of ectoparasites (ticks in 10 stomachs, lice in 2 stomachs). Fourteen of the 18 stomachs contained remains of non-ectoparasitic arthropods: unidentified insect remains in 8 stomachs, aphid remains in 3 stomachs, Diptera larvae remains in 2 stomachs, adult Musca domestica remains in 1 stomach, ant remains in 1 stomach and arachnid remains in 2 stomachs. All 32 stomachs contained hairs of Glis glis. Twelve stomachs contained moss remains.

The results broken down by sex are listed in Table 2 . Our results indicate that blackberries made up a significantly greater proportion of the diet of females than of the diet of males (comparison of percentage of individual-stomach dry weight accounted for by blackberry remains by the Mann-Whitney $U$ test: $z=-1.9, p<0.05$ ). The same is true of animal prey (Mann-Whitney $U$ test: $z=-2.6, p<0.01$ ).

Table 1. Stomach contents of the 32 individuals of Glis glis. \% F - percentage of stomachs containing remains of the type indicated, \% TW - percentage of total dry weight accounted for by the food type indicated, $\% \mathrm{Wm}$ - mean percentage of individual-stomach dry weight accounted for by the food type indicated. $\mathrm{Hm}$ (mean trophic diversity) $=0.12(\mathrm{SE}=0.03, \mathrm{SD}=0.19) ; \mathrm{Hz}$ (cumulative trophic diversity) $=1.17$ (Hurtubia 1973, see also Pielou 1975).

\begin{tabular}{lccc}
\hline Food type & $\% \mathrm{~F}$ & $\% \mathrm{TW}$ & $\% \mathrm{Wm}$ \\
\hline Nuts (acorns and hazelnuts) & 81.2 & 86.5 & 78.0 \\
Blackberries (Rubus sp.) & 50.0 & 10.2 & 12.6 \\
Birch seeds & 6.2 & 0.02 & 0.02 \\
Vegetative plant structures & 21.9 & 3.3 & 9.4 \\
Arthropods & 56.2 & 0.01 & 0.02 \\
\hline
\end{tabular}


Table 2. Stomach contents of the 17 males and 14 females of Glis glis. \% F and \% Wm as defined in the legend to Table 1.

\begin{tabular}{lccccc}
\hline \multirow{2}{*}{ Food type } & \multicolumn{3}{c}{$\% \mathrm{~F}$} & & \multicolumn{2}{c}{$\% \mathrm{Wm}$} \\
\cline { 2 - 3 } \cline { 5 - 6 } & Males & Females & & Males & Females \\
\hline Nuts & 88 & 71 & & 86.6 & 66.0 \\
Blackberries & 35 & 64 & & 1.6 & 26.8 \\
Birch seeds & 6 & 7 & & 0.003 & 0.032 \\
Vegetative plant structures & 12 & 36 & & 11.8 & 7.1 \\
Arthropods & 47 & 43 & & 0.001 & 0.4 \\
\hline
\end{tabular}

\section{Discussion}

The present results indicate that the autumn diet of the edible dormouse in our study area almost exclusively comprises plant material. Similar results have been obtained in previous studies. Kahmann (1965) found that the diet of an Italian population in August comprised largely nuts and blackberries. Holišova (1968) examined the stomach contents of 30 edible dormice from Czechoslovakia, and found that nuts (especially hazelnuts) constituted an important part of the diet, with leaves and other vegetative plant material present only in small amounts. In studies in the Iberian Peninsula, Castroviejo et al. (1974) and Castién (1994) have reported that the autumn diet is almost exclusively made up of nuts (beechnuts and hazelnuts) and, in the former, blackberries.

Animal remains are present in only very small amounts in the stomachs of edible dormice, and are probably largely the result of accidental ingestion of insects and other invertebrates present in or on plant food items (Holišova 1968).

In the present study, we have not detected any vertebrate remains. Previous studies have reported the occasional predation on birds (Vietinghoff-Riesch 1960, Storch 1978, Robel and Leitenbacher 1993). It seems likely that such behavior indicate predation of nestlings in man-made nest-boxes, since in areas where nest-boxes are present they are frequently occupied by edible dormice during the active season (Gaisler et al. 1977, Pilastro 1990, 1992, Robel and Leitenbacher 1993, Schlund et al. 1993). Nest-boxes are not present in our study area.

The presence of hair and ectoparasite remains in the stomach is almost certainly due to accidental ingestion during grooming. Likewise, the ingestion of moss is almost certainly accidental.

Our results indicate that the autumn diets of mainly sub-adult males and females are similar, though blackberries and animal remains were significantly more frequent in the stomachs of females. This result may indicate that accidental ingestion of small animals is particularly frequent during feeding on blackberries, though a larger sample would be necessary to confirm this hypothesis. 
Acknowledgements: We would like to thank J. Higueras, Director of the nature reserve of Montes do Invernadeiro, and the Service of Environment of the Xunta de Galicia for facilitating our field work. We thank the two anonymous referees who kindly revised the paper for their comments. This study was financed by the grant XUGA20011B96.

\section{References}

Castién E. 1994. Estudio bioecológico de la comunidad de micromamíferos (Insectivora y Rodentia) de un hayedo acidófilo, (Quinto Real, Navarra). Ph D thesis, University of Barcelona, Barcelona: $1-668$.

Castroviejo S. 1977. Estudio sobre la vegetación de la Sierra del Invernadeiro (Orense). Ministerio de Agricultura, Instituto Nacional para la Conservación de la Naturaleza, Madrid: 1-102.

Castroviejo J., Garzón J., Palacios F. and Castroviejo S. 1974. Sobre el lirón gris (Glis glis pyrenaicus Cabrera, 1908) en España. Doñana Acta Vertebrata 1: 121-142.

Franco D. 1990. Feeding habits of a dormouse population (Myoxus glis) of the Asiago Plateau (Venetian pre-Alps). Hystrix 2: 11-22.

Gaisler J., Holas V. and Homolka M. 1977. Ecology and reproduction of Gliridae (Mammalia) in northern Moravia. Folia Zoologica 26: 213-228.

Gigirey A., Carro F., Blanco B., Peña P. and Rey J. M. 1996. Importancia trófica de los frutos secos en una población de lirón gris (Glis glis L., 1776) en Galicia. Boletín de la Real Sociedad Española de Historia Natural. Tomo extraordinario, XII Bienal: 208-210.

Holišova V. 1968. Notes on the food of dormice (Gliridae). Zoologické Listy 17: 109-114.

Hurtubia J. 1973. Trophic diversity measurement in sympatric predatory species. Ecology 54: 885-890.

Kahmann H. 1965. Le loir (Glis glis L. 1776) dans le Monts Gargano Italie (Apulie). Mammalia 29: $72-94$.

Korschgen L. J. 1971. Procedures for food-habits analysis. [In: Wildlife Management Techniques. Robert H. Giles Jr, ed]. The Wildlife Society, Washington: 233-250.

Morris P. A. and Hoodless A. 1992. Movements and hibernaculum site in the fat dormouse (Glis glis). Journal of Zoology, London 228: 685-687.

Pielou E. C. 1975. Ecological diversity. John Wiley and Sons, New York: 1-165.

Pilastro A. 1990. Studio di una popolazione di ghiro (Glis glis Linnaeus) in un ambiente forestale del Colli Berici. Lavori-Societä Veneziana di Scienze Naturali 15: 145-155.

Pilastro A. 1992. Communal nesting between breeding females in a free-living population of fat dormouse (Glis glis L.). Bolletino di Zoologia 59: 63-68.

Robel K. and Leitenbacher G. 1993. Der Einfluß des Siebenschläfers Glis glis auf die Höhlenbrüterpopulation in künstlichen Nisthöhlen am Surspeicher. Ornithologischer Anzeiger 32: 59-63.

Rodolfi G. 1994. Dormice, Glis glis, activity and hazelnut consumption. Acta Theriologica 39: 215-220.

Schlund W., Stauss M. J., Burkhardt J. F. 1993. Siebenschläfer in Nistkästen - eine Langzeitstudie zur Habitatwahl. Carolinea 5l: 93-100.

Storch G. 1978. Glis glis (Linnaeus 1776). [In: Handbuch der Säugetiere Europas, Band 1. Rodentia 1. J. Niethammer and F. Krapp, eds]. Akademische Verlagsgesellschaft, Wiesbaden: 243-258.

Teerink B. J. 1991. Hair of West-European mammals. Cambridge University Press, New York: 1-224.

Vietinghoff-Riesch v A. 1960. Der Siebenschläfer (Glis glis L.). Monographie der Wildsäugetiere, 14. Gustav Fischer Verlag, Jena: 1-196.

Received 20 July 1997, accepted 24 June 1998. 